\title{
KAJIAN PERUBAHAN PENUTUPAN LAHAN PADA DAS CILIWUNG HULU DENGAN PENDEKATAN SPASIAL DINAMIK
}

\section{Study of Land Cover Changing in Ciliwung Upper Stream with Spatial Dynamic Approach}

\section{Dedi Ruspendi}

Mahasiswa Program Studi Arsitektur Lanskap 2011, Sekolah Pascasarjana IPB e-mail: ruspendi@gmail.com

\section{Setia Hadi}

Staf Pengajar Departemen Arsitektur Lanskap Fakultas Pertanian, IPB

\section{Omo Rusdiana}

Staf Pengajar Departemen Silvikultur, Fakultas kehutanan, IPB

\begin{abstract}
Land cover changing that occurs in Ciliwung Upper Stream resulted increasing the water level in the main river. It is describe that environmental quality of the upstream has decreased. Based on toposequent, the damage in upstream will affect to middle and downstream of watershed. This study aims to analysis the pattern and distribution of land cover change and build Ciliwung Upper Stream model in spatial planning based on carrying capacity. The research was conducted in Ciliwung Upper Stream that located in Bogor region. The method was used in this study compare landcovering 1999 and 2010. This study results patterns and distribution of land coverchange then use as input to analysis of spatial dynamic. Analysis of the spatial dynamic results a good composition of land cover in the Ciliwung Upper Stream. Land cover composition showed in table and spatial. Increasing of land cover has a high infiltration capacity can reduce the water level.
\end{abstract}

Keyword: land cover changing, water level, spatial dynamic, watershed

\section{PENDAHULUAN}

Daerah aliran sungai (DAS) Ciliwung memiliki nilai yang sangat strategis di Indonesia. Berdasarkan toposekuen, DAS Ciliwung dibagi menjadi tiga bagian, yaitu bagian hulu, tengah dan hilir. Sebagai suatu ekosistem DAS, perubahan bagian hulu DAS akan mempengaruhi seluruh bagian lainnya.Letak ibu kota negara di bagian hilir DAS Ciliwung menjadikan kawasan ini memiliki nilai strategis dalam pengembangan dan pengelolaannya.

Pembangunan yang pesat di daerah hulu DAS Ciliwung ditandai dengan alih fungsi lahan yang menyebabkan menurunnya fungsi kawasan ini sebagai daerah penyangga. Berdasarkan data BPDAS Citarum Ciliwung (2007), telah terjadi kenaikan debit maksimum. Sebelum tahun 1998 debit maksimum di Sungai Ciliwung adalah <200 m3/dtk, tetapi setelah tahun 1998 kondisi debit air DAS Ciliwung terus menunjukan kenaikan. Banjir tahun 1996, 2002 dan 2007di DKI Jakarta menyebabkan terjadinya perubahan pola tutupan lahan di kawasan hulu.

Kejadian banjir berhubungan erat dengan curah hujan yang tidak mampu terserap tanah karena daerah resapan air yang berkurang. Kondisi penutupan lahan (land cover) merupakan indikator penting dalam mengenali kondisi keseluruhan DAS, terutama dalam kaitannya dengan daerah resapan air. Komposisi penutupan lahan yang baik sangat diperlukan guna menghindari kejadian terjadinya banjir di hilir.

Pada jumlah lahan yang tetap, maka variasi tutupan lahan semakin bersaing. Penggunaan yang bernilai ekonomis tinggi akan menjadi pilihan uatama bagi pemilik lahan. Oleh karena itu, perlu dilakukan kajian agar alokasi pemanfaatan ruang sesuai dengan kondisi dan daya dukung lingkungannya. Tujuan dari penelitian ini yaitu: 1) menganalisis pola perubahan dan distribusi penutupan lahan DAS Ciliwung Hulu, 2) membangun model perubahan tutupan lahan DAS Ciliwung Hulu yang optimal.

\section{METODE PENELITIAN}

\section{Lokasi dan Waktu Penelitian}

Penelitian dilakukan di Sub-DAS Ciliwung Hulu yang berada pada wilayah administrasi Kabupaten Bogor, Provinsi Jawa Barat. Secara geografis terletak pada 6037'30" 6o46'10" LS dan 106049'36" 107o0'15" BT. Luas wilayah DAS Ciliwung Hulu adalah 15.265 ha. Penelitian ini dilakukan pada bulan Februari - September 2013.

\section{Metode}

Tahapan dalam penelitian ini dibagi menjadi dua tahapan, yaitu sistem dinamik dan analisis distribusi spasial.

\section{Sistem dinamik}

Pendekatan model sistem dinamik digunakan untuk memahami suatu masalah kompleks berdimensi waktu, dalam hal ini adalah perubahan tutupan lahan. Pendekatan ini menyederhanakan masalah sehingga mudah dipahami. Perubahan tutupan lahan didapatkan dari analisis tutupan lahan dengan cara menumpang tindihkan 2 peta yang memiliki rekaman tahun berbeda. Jenis tutupan lahan dihasilkan dari klasifikasi citra dengan metode klasifikasi terbimbing (supervised classification). Klasifikasi terbimbing dilakukan terlebih dahulu dengan menentukan sampel poligon/ training sample (AOI) yang mewakili tiap tutupan lahan yang dibuat.

Pola perubahan tutupan lahan ini juga menjadi bagian dalam tahapan sistem dinamik yang dikemukakan oleh Hartrisari (2007), yaitu identifikasi sistem melalui diagram sebab akibat (causal loop). Pola tersebut dibuat menjadi struktur model perubahan tutupan lahan di daerah penelitian. Struktur model yang dibangun menjelaskan hubungan perubahan tutupan lahan 
dengan debit maksimum air sungai. Prediksi debit maksimum air sungai dihasilkan dari analisis regresi linear berganda dengan komponen tutupan lahan dan curah hujan. Model regresi yang dibangun dengan $n$ variabel bebas yaitu:

$y=a+b x_{1}+c x_{2}+d x_{3}+e x_{4}+f x_{5}+g x_{6}+h x_{7}$

Dimana:

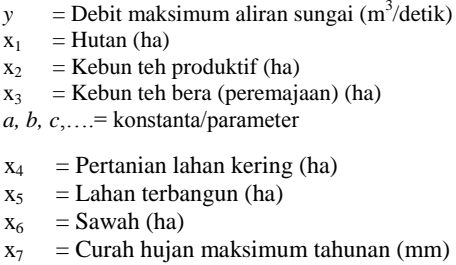

Sementara variabel curah hujan didalam model menggunakan curah hujan maksimum tahunan yang didapat dari periode ulang hujan. Periode ulang hujan yang digunakan adalah periode ulang hujan 15 dan 30 tahunan yang didapat dari curah hujan selama 30 tahun terakhir. Menurut Asdak (2007), periode ulang hujan ditentukan dengan rumus:

$$
T=(n+1) / m
$$

$\mathrm{T}$ : kejadian hujan berulang untuk $\mathrm{m}$ pengamatan data hujan

$\mathrm{n}$ : jumlah total pengamatan kejadian hujan

$\mathrm{m}$ : nomor peringkat untuk pengamatan kejadian hujan tertentu

2. Analisis Spasial Distribusi Tutupan Lahan (Spasial Dinamik)

Pendekatan spasial dinamik dilakukan dengan cara mengintegrasikan hasil analisis sistem dinamik dengan sistem informasi geografis sehingga mampu memperlihatkan distribusinya secara spasial (Rusdiana et.al, 2012). Menurut Nopiyanto (2009), logika model yang dipergunakan dalam penentuan distribusi yaitu: 1) model dinamik menghasilkan keluaran berupa luasan masing-masing tutupan lahan yang direkomendasikan dalam bentuk angka (hektar), 2) area penelitian dibagi menjadi kotak-kotak kecil (grid) dengan luas yang sama untuk setiap sel, 3) setiap sel merepresentasikan jenis tutupan lahan.

Dinamika perubahan tutupan menggunakan kriteria tertentu, seperti: 1) penambahan hutan akan dialokasikan pada lahan dengan kemiringan $>40 \%$ dan lahan yang sangat peka erosi yang mempunyai kemiringan $>15 \%$, 2) penambahan lahan terbangun pada lahan-lahan pertanian yang memiliki aksesibilitas jalan dan dekat dengan lahan terbangun lainnya (ketetanggaan).

\section{HASIL DAN PEMBAHASAN}

\section{Karakteristik Wilayah Penelitian}

\section{Karakteristik Sosial Budaya Dan} Ekonomi

Kegiatan ekonomi masyarakat lokal pada daerah penelitian terus mengalami pergeseran. Pergeseran tersebut terlihat pada jenis pekerjaan yang dahulu disektor pertanian (onfarm) beralih ke sektor nonpertanian, seperti jasa dan perdagangan. Pergeseran ini disebabkan oleh tingginya alih fungsi lahan dan alih kepemilikan lahan.

Tingginya harga lahan mendorong masyarakat lokal untuk menjual lahan kepada investor. Selain itu, kecenderungan kaum muda yang memilih bekerja diluar sektor pertanian seperti tukang ojeg, penjaga villa, joki (penunjuk arah) dan pedagang asongan membuat kegiatan ekonomi berbasis lahan sulit dipertahankan lagi. Pertambahan jumlah penduduk juga menjadi pendorong laju konversi lahan. Keadaan ini akan berakibat buruk terhadap kondisi DAS Ciliwung dimana daaerah tangkapan hujan akan semakin sedikit.

\section{Penguasaan Lahan Infrastruktur Jalan}

Penguasaan lahan di daerah hulu dapat dikelompokkan menjadi lahan negara, hak guna usaha dan hak milik.Lahan negara dalam bentuk kawasan hutan dikelola oleh pemerintah seperti Balai Taman Nasional Gede-Pangrango (Kawasan Taman Nasional), Balai Konservasi
Sumberdaya Alam (Kawasan Hutan Cagar Alam Telaga Warna) Departemen Kehutanan dan Perum Perhutani (Kawasan Lindung dan Produksi). Lahan dalam bentuk hak guna usaha digunakan sebagai kebun teh (PT Gunung Mas dan PT Ciliwung). Lahan milik umumnya digunakan untuk lahan pertanian, pemukiman, tempat peristirahatan, lahan komersil dan tempat rekreasi.

Berdasarkan BPDAS Citarum Ciliwung (2011) dan survey lapang (2013), penguasaan lahan di DAS Ciliwung Hulu sebagian besar sudah dimiliki oleh orang diluar kawasan penelitian. Lahan-lahan milik ini banyak berubah menjadi lahan terbangun jika terdapat akses jalan terhadap lahan tersebut. Akses jalan menjadi faktor dalam konversi lahan pada lahan milik.

\section{Karakteristik Hidrologi}

Kejadian banjir pada daerah hilir tidak bisa dilepaskan dari curah hujan pada daerah hulunya (BPDAS Citarum Ciliwung 2003). Data curah hujan maksimum harian stasiun Gunung Mas (1983-2010) menghasilkan nilai curah hujan maksimum harian untuk periode ulang 5 tahunan sebesar $141 \mathrm{~mm}, 10$ tahunan sebesar $157 \mathrm{~mm}, 15$ tahunan $162 \mathrm{~mm}$ dan 30 tahunan sebesar 247 mm. Data debit Pintu Air Katulampa tercatat pada kejadian banjir di DKI Jakarta pada tahun 2002 adalah 247,6 m3/dtk dan tahun 2007 sebesar 278,5 $\mathrm{m} 3 / \mathrm{dtk}$.

\section{Perubahan Pola Penutupan Lahan}

Hasil analisis citra landsat menunjukan bahwa pertanian lahan kering merupakan lahan yang banyak mengalami pengurangan, yaitu sebesar 9\% dari luas 5303 ha pada tahun 1999 menjadi 4115 ha pada tahun 2010. Pengurangan yang cukup besar juga terjadi pada tutupan lahan sawah, hutan dan kebun teh bera yang masing-masing sebesar 2\%, 2\% dan 0\%. Seiring dengan pengurangan luas tutupan lahan tersebut maka terjadi penambahan luas lahan lainnya, yaitu pada lahan terbangun sebesar $10,9 \%$ dan kebun teh produktif sebesar $2 \%$.

Model Regresi Linear Berganda 
Hubungan antara curah hujan maksimum tahunan dan tutupan lahan terhadap debit maksimum aliran sungai diperoleh persamaan sebagai berikut:

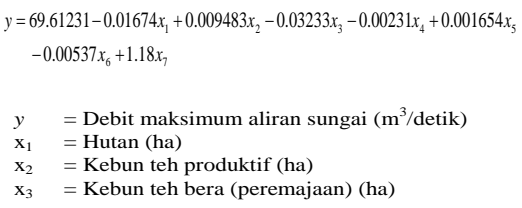

Debit banjir (aliran permukaan) yang dihasilkan tidak terlepas dari kemampuan tiap tutupan lahan dalam menginfiltrasikan air hujan yang jatuh.

Kapasitas infiltrasi juga memperkuat hasil dari regresi tentang hubungan dari tutupan lahan terhadap debit maksimum, dimana pada tutupan lahan yang mempunyai kapasitas infiltrasi yang relatif besar memiliki hubungan negatif terhadap debit maksimum. Sebaliknya pada tutupan lahan yang memiliki kapasitas infiltrasi rendah memiliki hubungan yang positif.

\section{Pembangunan Model Sistem Dinamik}

DAS merupakan sebuah sistem, ekosistem bagian hulu adalah bagian yang paling penting karena mempunyai fungsi perlindungan tehadap seluruh bagian DAS lainnya. Perubahan tutupan lahan didaerah hulu akan memberikan dampak pada keseluruhan wilayah DAS, mulai dari hulu sampai hilir. Kawasan yang awalnya bervegetasi banyak yang terkonversi menjadi lahan terbangunakan mengurangi kapasitas infiltrasi terhadap air hujan yang jatuh. Akibatnya pada musim penghujan air banyak yang terbuang ke hilir (banjir kiriman) dan pada musim kemarau debit air akan menjadi kecil sehingga berpotensi terhadap kekeringan pada daerah hilirnya.

Struktur model yang dibangun terbagi menjadi 2 submodel, yaitu submodel perubahan tutupan lahan dan submodel hidrologi. Submodel perubahan tutupan lahan terdiri dari tutupan lahan pada wilayah penelitian dan pola perubahannya. Pada submodel hidrologi, pola perubahan tutupan lahan akan berinteraksi dengan curah hujan periode ulang 15 dan 30 tahunan sehingga menghasilkan debit maksimum.

\section{Validasi Model}

Validasi dilakukan untuk memperoleh tingkat kepercayaan kinerja model yang dibuat sesuai dengan kinerja sistem nyata. Validasi model menggunakan uji $\mathrm{t}$ (two tail) dengan taraf kepercayaan 5\%. Hasil uji $\mathrm{t}$ menunjukan bahwa nilai $\mathrm{t}$ hitung berada pada daerah tidak beda nyata, sehingga model yang dihasilkan dapat dikatakan mampu merepresentasikan sistem nyata.

\section{Simulasi Model}

Pada penelitian ini skenario akan dibagi menjadi empat skenario dan pada dua keadaan hujan. Dasar pembuatan skenario adalah peluang kemungkinan terjadinya dinamika perubahan tutupan lahan yang akan terjadi pada kawasan penelitian (Gambar 1). Beberapa skenario yang disusun adalah sebagai berikut:

1. Skenario 1, adalah skenario eksisting, skenario yang disusun menyerupai dinamika yang terjadi di lapangan atau tanpa adanya perencanaan.

2. Skenario 2, adalah skenario yang disusun bahwa perubahan tutupan lahan hanya terjadi pada lahan-lahan pertanian (lahan milik). Hutan dan perkebunan teh akan tetap karena statusnya yang dikuasai oleh pemerintah. Laju perubahan pertambahan lahan terbangun sesuai dengan dinamika laju saat ini.

3. Skenario 3, adalah skenario yang disusun bahwa lahan-lahan diluar lahan terbangun berubah semua menjadi pertanian lahan kering. Lahan hutan dan perkebunan teh tetap.

4. Skenario 4, adalah skenario yang disusun menyerupai RTRW Kabupaten Bogor.

Variabel yang digunakan dalam simulasi adalah variabel tutupan lahan dalam hektar, variabel curah hujan periode ulang 15 tahun (162 $\mathrm{mm}$ ) dan 30 tahun (247 $\mathrm{mm})$, dan yang menjadi pengendali adalah debit maksimum Sungai Ciliwung di Pintu Air Katulampa sebesar 247,6 m3/dtk (kejadian banjir DKI Jakarta tahun 2002).

Hasil simulasi pada skenario 1 menunjukan tutupan lahan hutan terus mengalami pengurangan. $\mathrm{Hal}$ ini diakibatkan banyaknya konversi lahan hutan menjadi pertanian lahan kering. Konversi lahan ini akan banyak terjadi pada kawasan hutan yang langsung berbatasan dengan areal pertanian masyarakat. Sementara pada skenario 2 dan 3, areal hutan tetap dan pada skenario 4 luas hutanbertambah.

Pada semua skenario luas tutupan lahan terbangun bertambah sesuai dengan keadaan yang sudah terjadi dilapangan, dengan kata lain pertambahannya mengukuti laju dilapangan pada saat ini. Luas diakhir simulasi lahan terbangun pada semua skenario berkisar 4.500 5.000 ha.

Sementara pada lahan-lahan pertanian, terutama pertanian lahan kering pada skenario 1, 2 dan 4 luasannya mengalami pengurangan karena areal ini banyak mengalami alih fungsi menjadi lahan terbangun. Pada skenario 3 pertanian lahan kering bertambah diawal simulasi karena adanya konversi lahan dari sawah menjadi pertanian lahan kering.Areal lainnya yang mengalami perubahan adalah pada areal kebun teh (skenario 4). Perkebunan teh yang telah habis masa hak guna usahanya direncanakan untuk dikonversi menjadi lahan hutan. Perkebunan teh yang telah habis masa hak guna usahanya adalah PT. Ciliwung 

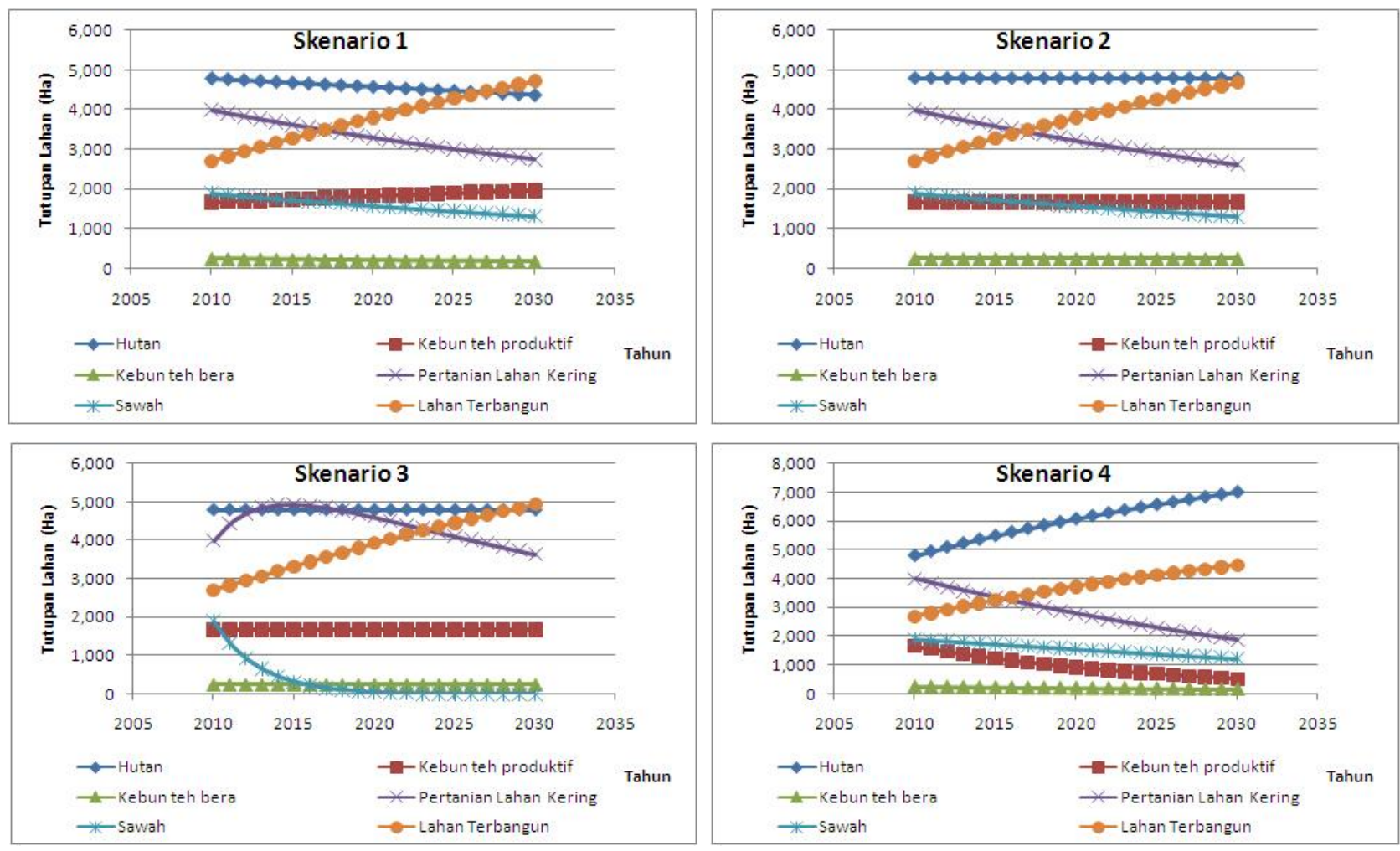

Gambar 1. Grafik Perubahan Tutupan Lahan Skenario 1,2,3, dan 4

(Kompasiana, 18 Juni 2011). Hal ini terdapat dalam RTRW Kabupaten Bogor hingga tahun 2025 dimana kawasan pada areal perkebunan teh PT. Ciliwung direncanakan untuk kawasan hutan lindung.

Pada debit maksimum, hasil simulasi menunjukan bahwa pada periode ulang hujan 15 tahunan debit maksimum yang dihasilkan pada semua skenario tidak melebihi debit bahaya yang pernah terjadi ditahun 2002. Meskipun demikian, debit maksimum yang dihasilkan tersebut terus menunjukan peningkatan setiap tahunnya. Dengan curah hujan sebesar $162 \mathrm{~mm}$ komposisi tutupan lahan pada DAS Ciliwung Hulu masih mampu menampung dan menginfiltrasikan air hujan yang jatuh.

Sementara pada periode ulang hujan 30 tahunan, dimana curah hujan sebesar $247 \mathrm{~mm}$ komposisi tutupan lahanpada skenario 1,2 dan 3 pada akhir simulasi tidak mampu menampung dan menginfiltrasikan air hujan sehingga air hujan yang jatuh banyak yang menjadi air larian. Hal ini diakibatkan oleh penurunan luas lahan hutan (skenario 1) dan penambahan luas lahan terbangun. Penurunan luas lahan hutan menjadi pertanian lahan kering membuat lahan tersebut lebih terbuka, sehingga air hujan yang jatuh dapat langsung jatuh ke tanah tanpa adanya intersepsi oleh tajuk hutan terlebih dahulu. Penambahan lahan terbangun akan menambah luasan lahan yang memiliki sifat relatif kedap terhadap air hujan.

Sementara pada skenario 4 , terdapat penurunan debit maksimum pada periode ulang hujan 30 tahunan dari awal simulasi hingga akhir simulasi. Hal ini dikarenakan terdapat penambahan lahan hutan pada areal penelitian. Menurut Arsyad (2012), keberadaan hutan dengan akarnya akan memperbaiki struktur tanah sehingga dapat meningkatkana kapasitas infiltrasi tanah. Keuntungan lainnya dengan adanya tajuk hutan, air hujan yang jatuh mampu diintersepsi hingga 10-35\% (Asdak 2007).

Dengan mempertimbangkan hasil dari keempat skenario, maka skenario 4 adalah skenario terbaik yang dapat diterapkan pada kawasan penelitian.Dengan skenario 4, debit maksimum yang dihasilkan berada dibawah debit bahaya pada akhir simulasi. Dengan komposisi tutupan lahan pada skenario 4 kondisi DAS Ciliwung Hulu akan mengalami perbaikan.

Berdasarkan hasil analisis menggunakan sistem informasi geografis, disajikan dinamika perubahan hasil skenario 4 yang dapat dilihat pada Gambar 2.

\section{Arahan Pengembangan}

Dari hasil analisis dan pembahasan dapat ditentukan beberapa rekomendasi dalam penataan Kawasan DAS Ciliwung Hulu untuk mencapai tujuan akhir dari skenario 4, yaitu: 1) mempertahankan kawasan hutan yang ada pada saat ini di kawasan penelitian (hutan konservasi dan hutan lindung), 2) menambahan luas tutupan lahan hutan diluar kawasan hutan melalui sistem agroforestri sebesar 2.211 ha atau 15\% dari luas DAS Ciliwung Hulu yang tersebar pada lahan kebun teh PT. Ciliwung dan pertanian lahan kering disekitar/pinggir kawasan hutan, 3) pengaplikasian teknologi konservasi tanah dan air pada lahan-lahan pertanian, 4) penegakan hukum bagi yang melanggar terkait peraturan koefesien dasar bangunan (KDB) dan koefesien dasar hijau $(\mathrm{KDH})$ dan 5) pengaplikasian sumur resapan pada lahan terbangun terutama pada daerah yang padat bangunan. 
Pola perubahan tutupan lahan di DAS Ciliwung Hulu terdapat delapan tipe. Pola perubahan dengan luasan yang terbesar adalah pertambahan lahan terbangun sebesar 1.707 ha $(11 \%)$. Pertambahan lahan terbangun ini banyak mengkonversi pertanian lahan kering dan lahan sawah. Pertambahan lahan terbangun tersebut banyak terjadi (terdistribusi) pada wilayah yang dilalui oleh akses jalan.Model perubahan tutupan lahan yang efektif untuk diterapkan pada DAS Ciliwung Hulu adalah skenario 4. Penambahan luas lahan hutan sebesar 2211 ha (15\%) dapat mengurangi debit maksimum yang dihasilkan hingga berada dibawah debit bahaya.

\section{Saran}

Pada penelitian ini, hasil regresi menunjukan signifikansi yang relatif kecil sehingga diharapkan pada penelitian selanjutnya dilakukan penambahan variabel 1 ain seperti topografi, jenis tanah, dll. Selain itu,perlu juga dilakukan kajian lanjutan untuk daerah tengah dan hilir DAS Ciliwung, guna melihat akibat dari perubahan tutupan lahan dari daerah tersebut terhadap air lariannya (debit sungai).

\section{DAFTAR PUSTAKA}

Arsyad S. 2012. Konservasi Tanah dan Air. Bogor. IPB Press. Edisi Kedua Cetakan Ketiga.

Asdak C. 2007. Hidrologi dan Pengelolaan Daerah Aliran Sungai. Yogyakarta. Gadjah Mada University Press.

BPDAS Citarum Ciliwung. 2003. Rencana Pengelolaan DAS Terpadu DAS Ciliwung. Bogor: BPDAS Ciliwung Citarum.

2007. Penyusunan Rencana Detail Penanganan Banjir di Wilayah Jabodetabekjur. Bogor : BPDAS Ciliwung Citarum.
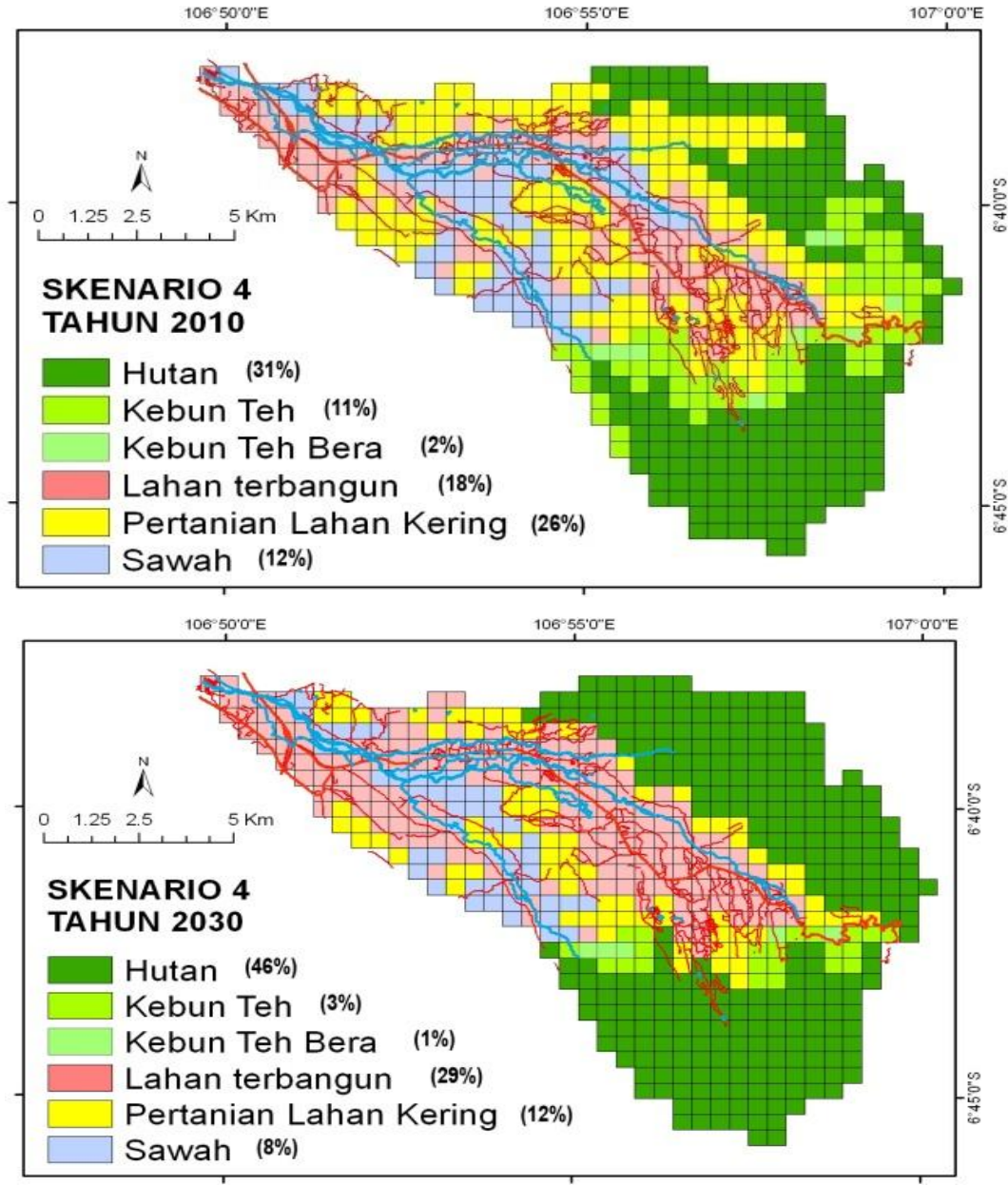

Gambar 2. Dinamika Distribusi Tutupan Lahan Hasil Skenario 4

2011.

gan Peningkatan Fungsi dan Daya Dukung Ekologi dalam Pengelolaan DAS Ciliwung. Bogor : BPDAS Ciliwung Citarum.

Hartrisari. 2007. Sistem Dinamik: Konsep Sistem dan Pemodelan untuk Industri dan Lingkungan. Bogor. SEAMEO BIOTROP.

Kuswadi D. 2002. Model Pendugaan Debit Berdasarkan Data Cuaca di Daerah Aliran Sungai (DAS) Ciliwung Hulu. [Tesis]. Program Pascasarjana, Institut Pertanian NopiyBagøH.H. 2009. Perencanaan Lanskap Kota Sintang Berkelanjutan dengan Pendekatan Model Spasial Dinamik. [Tesis]. Program Pascasarjana, Institut Pertanian Bogor.

Rusdiana O, Hadi S dan Suwarto. 2012. Seminar dan Ekspose Hasil-Hasil
Kegiatan dan Penelitian P4WLPPM IPB. Bogor Syariful. 2011. 5ooo Pekerja Teh di-PHK, akankah Kawasan Resapan Air dan Hulu Sungai Ciliwung Terancam. Kompasiana Regional [internet]. [diacu 2013 Agustus 27]. Tersedia dari:

http:/ / regional.kompasiana.com/2 011/06/17/5000-pekerja-teh-diphk-akankah-kawasan-resapan-airdan-hulu-sungai-ciliwungterancam-373708.html

Syartinilia. 2004. Penerapan Multi Criteria Decision Making (MCDM) dan Geographical Information System (GIS) pada Evaluasi Peruntukan Lahan. [Tesis]. Program Pascasarjana, Institut Pertanian Bogor. $m$ (GIS) pada Evaluasi Peruntukan 